\title{
Probiotic Characterization of Lactic Acid Bacteria Isolated From Local Fermented Vegetables (Makdoos)
}

\author{
Adel M. Mahasneh ${ }^{1 *}$ and Sari A. Mahasneh ${ }^{2}$ \\ ${ }^{1}$ Department of Biological Sciences, Faculty of Sciences, the University of \\ Jordan Amman 11942, Jordan \\ ${ }^{2}$ School of Dental Medicine, the University of Manchester, Manchester, UK \\ *Corresponding author
}

\section{A B S T R A C T}

\section{Keywords}

Lactobacillus,

Makdoos,

Fermented

vegetables,

Probiotics,

Properties, Caco-2.

Article Info

Accepted:

24 January 2017

Available Online:

10 February 2017
The present study aims at isolation and characterization of Lactobacillus species from Makdoos a locally stuffed and fermented vegetables and to characterize some selected isolates for their probiotic potential. Sixteen isolated Lactobacillus strains (7 Lactobacillus plantarum 1, 3 Lactobacillus pentosus, 1 Lactobacillus brevis 1, 1 Lactobacillus brevis 3, 1 Lactobacillus rhamnosus, 1 Lactobacillus salivarius and two were not fully assigned to a species were chosen for further testing. These were tested for their probiotic potential. This included survival at low $\mathrm{pH}$ and in gastrointestinal simulated juice, antagonistic activity against Salmonella typhimurium, Escherichia coli, Bacillus cereus and a methicillinresistant Staphylococcus aureus (MRSA) isolate, bile tolerance, antibiotic resistance to 8 antibiotics and adhesion to Caco-2 cells. Most isolates, especially Lactobacillus plantarum 1 , were tolerant to acidity and intestinal conditions after exposure for three and four hours respectively with reduction less than one log cycle of the starting CFU/ml. The same trend was observed in respect to bile tolerance with slight variations. All isolates inhibited the growth of the tested pathogens and were highly effective against Bacillus cereus, Salmonella typhimurium and MRSA isolate. As for antibiotic resistance, it was pronounced against tetracycline, streptomycin kanamycin, and trimethoprim. Some isolates, M5 and and M6 showed resistance to 6 or more of the 8 antibiotics tested and others were resistant to 3 or 4 antibiotics. As for adhesion ability to Caco-2 cells, some isolates showed superior ability i.e more than $80 \%$ relative adhesion compared with Escherichia coli and higher than the probiotic strain Lactobacillus reuteri DSMZ 20056. In Conclusion, the ability of these isolates to survive well under the tested conditions as well as being non-hemolytic renders them as good probiotic candidates for health and food technology benefits. Results also prove that the traditionally fermented vegetables are good sources for probiotic Lactobacillus. However, further in vivo studies are needed to substantiate their potential use in different applications.

\section{Introduction}

In the last few years, probiotics use for different puposes had aroused interest in different medicinal settings in different countries (Angmo et al., 2016). Lactic acid bacteria especially Lactobacillus species have been explored as probiotics due to the growing evidence of their health benefits (Feng et al., 2015; Tropcheva et al., 2014). 
Sources for the isolation of unique probiotic isolates vary according to geographic regions and dieting habits, however, human and animal gastrointestinal tracts played a great role in isolating promising probiotics (LievenLe et al., 2014). In the last decade new resources have been tested including dairy products (Carafa et al., 2015), fermented meat products (Rubio et al., 2014), foods of plant origin (Wang et al., 2014) and traditionally fermented and pickled vegetables (Mahasneh et al., 2015). Earlier studies were mainly concerened in the search for new starter cultures for different fermentations in food production and technology. Entering the probiotics era necessates characterization of these bacteria for the putative health benefits they provide, as well as searching traditionally fermented vegetables for superior probiotics. Characterization of such bacteria isolated from fermented vegetables is rather sparse and it focuses mainly on their antimicrobial activity. Few studies investigated probiotic attributes of bacteria of pickled and fermented vegetables. As a result more information is needed to substantiate the role of fermented vegetables derived probitics through studying their adhesion ability, cholesterol reduction, resistance to antibiotics and resistance to acid and bile and other characteristics both in vitro and in vivo.

The increased demand for complimentary and health food encourages innovation and new and novel product development in the food industries (Guo et al., 2010; Abbas et al., 2014). It is well established that consumption of probiotic bacteria as formulation or fermented food ingredients stimulates growth of beneficial bacteria and reduces pathogen activity (Chiang et al., 2012). To attain the health benefits of probiotic foods, it should contain no less than $10^{7} \mathrm{CFU}$ of viable bacteria per gram. In this cotext, probiotic fermented or fortified foods have received wide interest in an expanding market (Argyri et al., 2013). For Lactobacillus strains to exert the expected benefits as probiotics, they should fulfill all or most of the criteria laid down for probiotics in general including ability to survive in the gastrointestinal tract, tolerate bile salts as well as adhesion and persistence to resist pathogens through production of antimicrobial substances and other means (Lee et al., 2011; Tulini et al., 2013).

Lactic acid bacteria mainly Lactobacillus and Bifidobacterium species are considered very basic in probiotic development, however lactobacilli are the fundamental group. They thrive in naturally fermented or fortified dairy products. Recently, a drive towards non-dairy novel probiotics is observed to span traditionally fermented foods of vegetable origin, Feng et al., 2015). No doubt such traditionally fermented foods would be a unique mining area for new and novel probiotic Lactobacillus isolates. It is recognized that wild probiotic strains would compete better in food traditional fermentation settings. Accordingly, new and novel specific probiotic candidate bacterial strains are being sought. The efficacy of such strains is mandatory and should be carefully evaluated for safety.

In Jordan, pickled and traditionally fermented vegetables form a reasonable part of the home-made stored foods. Makdoos in its different forms, is an example, it is made traditionally of fermented aubergine stuffed with ground walnuts, garlic, hot dried pepper and left to ferment in vegetable oil, mainly olive oil (24.8) The other type of Makdoos is the big green pepper Makdoos which is stuffed with cut tomato, parsley, garlic and hot dried pepper and traditionally soaked and fermented in vegetable oil preferably olive oil or a mixture of oil and water. The fermentation process starts with a wide variety of indigenous microorganisms present 
in / on the vegetables and the stuffing material used. However, the bacteria responsible for the major fermentation in this case are lactic acid bacteria mainly Lactobacillus spp.

Due to increasing concern of the interrelationship between diet and health, great attention is given to the functional properties of indigenous lactobacilli involved in traditional fermented foods (25.13.5.26). It is assumed that these foods could provide a rich source of new novel probiotics with unique properties. The aim of this study was to isolate and assess the pro biotic potential of some Lactobacillus species from Makdoos through studying some characteristics such as tolerance to gastrointestinal juice acid and bile), their antagonistic activity against some pathogens, their antibiotic resistance as well as studying their adhesion to Caco cells.

\section{Materials and Methods}

Collection of fermented vegetable samples (Makdoos) and bacterial growth enrichment.

Homemade and retail commercial samples were collected from Amman markets during the period 2013-2014 and included in this investigation. These samples of Makdoos were either single samples of stuffed and fermented vegetables or composite samples prepared when needed irrespect of their number. The enrichment process was carried out by inoculating approximately $1 \mathrm{ml}$ of a sample homogenate into $50 \mathrm{ml}$ sterile MRS broth (Oxoid, UK) and incubated anaerobically at $37^{\circ} \mathrm{C}$ for 2-5 days (13). All samples were collected into sterile glass samplers and were kept in the laboratory at room temperature for further analysis.

\section{Isolation of Lactobacillus strains}

Enriched Makdoos samples were serially diluted in sterile normal saline. Aliquots of
$100 \mu \mathrm{l}$ from each dilution were then plated onto de Man, Rogosa and Sharpe agar (MRS, Oxoid, UK) supplemented with $0.01 \%$ bromocresol purple as a $\mathrm{pH}$ indicator. Plates were incubated anaerobically using anaerogen bags (AnaeroGen, UK) at $37^{\circ} \mathrm{C}$ for 48 hours. Presumptive Lactobacillus colonies with yellow halos were randomly picked off the MRS plates and were further subcultured onto fresh plates of the same medium to ensure purity.

\section{Identification of bacterial strains}

All isolates were tested for catalase and oxidase activity, Gram reaction, cell morphology as well as spore formation (27.28). The strains were tested for production of acids from carbohydrates and related compounds using API $50 \mathrm{CH}$ kits and CHL media (BioMèrieux, France) according to the manufacturer's instructions. Results were scored after incubation at $37^{\circ} \mathrm{C}$ for 24 and 48 hours. These results were joined to the apiweb $^{\mathrm{TM}}$ identification software with database (V5.1) which uses the phenotypic data to predict a species identity.

Interpretations of the fermentations profiles were facilitated by comparing all results obtained for the tested isolates with information from the computer aided database. Isolates were also tested for their hemolytic patterns, gelatinase and DNase activity according to (Gupta et al., 2007).

\section{Maintenance of bacteria}

Bacterial cultures were maintained in MRS broth with $20 \%$ glycerol and kept stored at $80^{\circ} \mathrm{C}$. Working cultures were kept on MRS agar plates at $4^{\circ} \mathrm{C}$ and were routinely subcultured every 2-4 weeks. For comparative purposes, Lactobacillus reuteri DSMZ 20056, a probiotic strain, was included in some tests. 
Preparation of simulated gastric and intestinal juices

Fresh simulated gastric and intestinal juices were prepared daily by suspending pepsin (P7000-25G Sigma-Aldrich, USA) at 0.3\% $\mathrm{w} / \mathrm{v}$ and pancreatin USP (P-1500, SigmaAldrich, USA) at $0.1 \% \mathrm{w} / \mathrm{v}$ in sterile $0.5 \%$ $\mathrm{w} / \mathrm{v} \mathrm{NaCl}$. The $\mathrm{pH}$ was adjusted to 3.0 for gastric juices using $\mathrm{HCl}$ and $\mathrm{pH} 8.0$ for intestinal juices with $0.1 \mathrm{M} \mathrm{NaOH}$ using $\mathrm{pH}$ meter (Eutech 510, Singapore).

\section{Bacterial tolerance to simulated gastric and intestinal juices}

Overnight bacterial cultures grown in MRS broth of each test isolate were adjusted to 0.5 McFarland standard (to know the initial bacterial counts per $\mathrm{ml}$ ) and $30 \mathrm{ml}$ aliquot of that suspension was centrifuged $(2500 \mathrm{x} \mathrm{g}$, for 20 minutes, at $5^{\circ} \mathrm{C}$ ), washed twice in $50 \mathrm{mM}$ $\mathrm{K}_{2} \mathrm{HPO}_{4}$ (pH 6.5) and resuspended in $3 \mathrm{ml}$ of the same buffer. One milliliter of each isolate suspension was harvested by centrifugation $\left(12,000 \mathrm{x} \mathrm{g}\right.$, for 20 minutes, at $\left.5^{\circ} \mathrm{C}\right)$ and resuspended in $9 \mathrm{ml}$ of gastric solution.

Total viable counts on MRS plates were recorded, both before and after incubation period of 3 hours at $37^{\circ} \mathrm{C}$. Then, one milliliter of gastric juice was taken and added to $9 \mathrm{ml}$ of intestinal juice solution.

Total viable counts on MRS plates were also recorded, after an incubation period of 4 hours at $37^{\circ} \mathrm{C}$. The results were expressed as colony forming units $\left(\log _{10}\right.$ orders $\left.\mathrm{CFU} / \mathrm{ml}\right)$.

\section{Determination of total viable counts}

Total viable counts of Lactobacillus species were determined by spread plate method using MRS agar. Serial ten-fold dilutions were prepared using sterile normal saline. Triplicate plates of each suitable dilution were inoculated with $100 \mu \mathrm{l}$ each and incubated anaerobically (AnaeroGen, UK) at $37^{\circ} \mathrm{C}$ for 48 hours after which numbers of $\mathrm{CFU} / \mathrm{ml}$ were determined.

\section{Detection of antibacterial activity of the bacterial isolates}

For the detection of antagonistic activities of the isolates, an agar spot procedure was used. The antibacterial activity of the selected Lactobacillus isolates was determined by the test described by (13.30) with some modifications as follows: five microliters of each overnight culture of Lactobacillus isolate grown in MRS broth were spotted onto the surface of MRS agar plates (containing 0.2\% glucose) and were then incubated under anaerobic conditions at $37^{\circ} \mathrm{C}$ for 48 hours. An overnight culture of four indicator strains $(E$. coli ATCC 25922), (S. typhimurium ATCC 14028), (B. cereus toxigenic strain TS) and (MRSA clinical isolate) were grown in nutrient broth and were adjusted to 0.5 McFarland solution standard which is equivalent to about $10^{8} \mathrm{CFU} / \mathrm{ml}$. Aliquots of $0.25 \mathrm{ml}$ were inoculated into $7 \mathrm{ml}$ of soft/semi-solid nutrient agar (containing $0.2 \%$ glucose and $0.7 \%$ agar). Inoculated semi-solid agar was immediately poured in duplicates over the MRS plate on which the tested Lactobacillus isolate was grown. The plates were incubated aerobically to allow growth of the test pathogenic bacteria at $37^{\circ} \mathrm{C}$ for 24 hours. The antibacterial activity was detected by measuring the inhibition zones around the Lactobacillus bacterial spots. Inhibition was recorded as positive if the diameter of the zone around the colonies of the producer was $2 \mathrm{~mm}$ or more (Abbas et al., 2015). This result were further confirmed by testing the neutralized cell free culture supernatant by the agar diffusion assay to eliminate the probability of inhibition by the acid produced by isolates. 


\section{Bile tolerance test}

The tolerance of the bacterial isolates to bile was tested using MRS broth prepared with 0.3, 0.5, 1 and 2\% (w/v) oxgall (Oxoid, UK). Ten milliliter aliquots of bile solutions were transferred into standard test tubes and sterilized by autoclaving at $121^{\circ} \mathrm{C}$ for $15 \mathrm{~min}$. Bacterial cultures were inoculated into sterile MRS broth, incubated overnight and adjusted to $0.5 \mathrm{McFarland}$ turbidity standard at the time of use. Two hundred microlitres of the adjusted bacterial cultures were inoculated into different bile concentrations tubes for each isolate. One milliliter aliquots were taken from each inoculated bile tube at zero hours of incubation and after 24 hours, serially diluted with sterile normal saline and spread plated in triplicates onto MRS agar plates to determine total viable counts.

\section{Antibiotic susceptibility testing}

The antibiotic susceptibility test was done according to the agar diffusion method published by the National Committee for Clinical Laboratory Standards (NCCLS, 2000). The determination of minimum inhibitory concentration (MIC) to certain antimicrobial agents recommended by Scientific Committee on Animal Nutrition included Ampicillin, Ciprofloxacin, Erythromycin, Gentamicin, Kanamycin, Streptomycin, Tetracycline and Trimethoprim. Müller-Hinton agar (Merck, Darmstadt, Germany) plates were used and incubated under anaerobic conditions. Serial dilutions of antibiotics were prepared using sterile distilled water, DMSO and/or ethanol and were sterilized using $0.22 \mu \mathrm{m}$ syringe filters (Macherey-Nagel, Germany). One $\mathrm{ml}$ of each suitable antibiotic concentration was added to $9 \mathrm{ml}$ of molten agar, mixed thoroughly and poured into sterile petri dishes. The agar plates were allowed to set at room temperature. Bacterial inocula were prepared by suspending several bacterial colonies from fresh agar plates in normal saline to a $0.5 \mathrm{McF}$ arland turbidity standard. A spot of $4 \mu \mathrm{l}$ of the inocula was placed on the agar surface. The inoculated plates were allowed to stand at room temperature for about 30 minutes. The triplicate plates were then transferred into anerobic jars and were then incubated at $37^{\circ} \mathrm{C}$ for 24 hours. The MIC (Minimum Inhibitory Concentration) was recorded as the lowest concentration of the antimicrobial agent that completely inhibited growth.

\section{Adhesion to Caco -2 cells}

The test was conducted based on the method described by Balamurugan et al., (2014).To grow the Caco-2 cells, 10 percent v/v inactivated fetal calf serum, 1 percent nonessential amino acids, 1 percent glutamine and 20 microgram per $\mathrm{ml}$ of streptomycin and penicillin were added to Dulbeco's modified Eagle medium (DMEM). Caco-2 cells were added to this medim. Seeded into 24-well tissue culture plates at a concentration of 1 million cells per $\mathrm{ml}$ and incubated at $37 \mathrm{C}$ in 10 percent $\mathrm{CO} 2$ for seven days.

Medium was changed every two days. Bacterial isolates were grown in MRS broth, pelleted and washed and finally suspended in non-supplemented DMEM to a concentration equal to 3 Mcfaland standard. One $\mathrm{ml}$ of this suspension was overlaid onto caco- 2 cells monolayers and incubated at $37 \mathrm{C}$ in 10 percent $\mathrm{CO} 2$ for 90 minutes. The bacterial suspension was then removed via aspiration, DMEM was used to wash the cells and one $\mathrm{ml}$ of $0.1 \%$ Triton X-100 was added for 10 minutes to detach any bacterial cells that have adhered to the Caco -2 monolayer. The detached bacterial cells were then plated onto MRS agar at 1:100 and 1:1000 dilutions and then incubated at $37 \mathrm{C}$ in $10 \% \mathrm{CO} 2$ for 24 hours. Colonies were then counted after 
incubation and E. coli was used as a positive control i.e 100 percent relative adhesion.

\section{Statistical analysis}

The results are presented as means \pm SD. Statistical differences among bacterial isolates were determined by two way ANOVA except for tolerance to simulated gastric and simulated intestinal juices which were determined by three way ANOVA. Differences were considered significant at $\mathrm{p}<0.05$.

\section{Results and Discussion}

\section{Isolation and identification of Lactobacillus potential probiotic strains}

A total of sixteen isolates from different fermented samples were chosen to be used in this study. All isolates were Gram positive rods, catalase and oxidase negative, non-spore forming, non- hemolytic, and DNase as well as gelatinase negative (Table 1). Absence of hemolytic activity of these isolates is a positive sign in favour of being suitable probiotic isolates irrespect of being $L$. plantarum, $L$. pentosus, $L$. brevis or $L$. salivarius. Similar observations were recorded for Lactobacillus isolates from dairy and other sources. These isolates were further characterized using API $50 \mathrm{CH}$ strips. Results of the API 50 test confirmed the identity of the 16 Lactobacillus isolates (Table 2). Identification of the isolates (Table 2) indicated the dominant presence of Lactobacillus plantarum where 7 out of the 16 isolates belonged to this species, followed by 3 Lactobacillus pentosus isolates and 2 Lactobacillus brevis. One each of L.rhamnosus, L.salivarius, and two isolates were not designated to any species.

Probiotic lactobacilli have been isolated from foods of plants origin and cereals. It is recognized that wild type strains that dominate naturally fermented products tend to have higher metabolic capabilities thus affecting the final quality of the traditionally fermented product (Ayed et al., 2002). Feng et al., (2016) isolated lactobacilli from fermented vegetables and observed the same trend of $L$. plantarum being the dominant isolates. Liu et al., also isolated lactic strains from pickled vegetables with unique probiotic characteristics.

\section{Resistance to simulated gastrointestinal juices}

In order for probiotic candidates to exert their beneficial activity, they should survive exposure to gastrointestinal environment of low $\mathrm{pH}$ and other paramakers. The viable counts of all isolates of the different selected strains of Lactobacillus species for this test were less than or equal to $1 \log \mathrm{CFU} / \mathrm{ml}$ as compared with the zero time count (7-8 log $\mathrm{CFU} / \mathrm{ml}$ ). This was noted at both $\mathrm{pH} 3$ and 8 after $3 \mathrm{~h}$ and $4 \mathrm{~h}$ exposure, respectively. This high resistance was observed among $L$. plantarum 1 Y2, L. pentosus L 25 and $L$. rhamnosus $Y 1$ isolates (Table 3 ). Some $L$ plantarum 1 namely L23, L24 were not as tolerant as others where at $\mathrm{pH} 4$ viable counts were almost zero after $4 \mathrm{~h}$ at $\mathrm{pH}$ 8.Maragkoudakis et al. (34.38) tested acid resistance of probiotic bacteria isolated from different sources and reported results in agreement with those reported herein. Abbas and Mahasneh isolated Lactobacillus isolates from camel milk and they had a similar trend in tolerance to gastrointestinal juices as those observed in this investigation. L.plantarum from fermented vegetables and it was able to show high survival rate after exposure to $\mathrm{pH}$ 2.5 and 8.0 for 3 and 4 hours respectively.

\section{Antagonistic activity against pathogens}

All isolates inhibited the pathogenic target bacteria irrespect of being gram positive B.cereus or MRSA or gram negative E.coli or 
Salmonella typhimurium with varying degrees (Table 4). This is associated with the ability of these isolates to produce bacteriocins and other antimicrobials (Messaoudi et al., 2013) which needs further testing. Antibacterial substance production is a functional property to characterize probiotics (Shah, 2007). The ability to produce such compounds is very basic for competitive exclusion of pathogens and is a critical characteristic for probiotic bacterial candidates. Of interest is the superior antagonistic activity of $L$. rhamnosus $Y 1, L$. plantarum 1 Y2, R21, R22, L23, L24 and L.pentosus L 25. It is notable that L.rhamnosu Y1, though greatly inhibited both B.cereus and S.typhimurium,it mildly inhibited MRSA. R22 L.plantarum 1 also highly inhibited E.coli and B.cereus.

\section{Resistance to bile salts}

Most of L.plantarum1 isolates L23, L24 and Y2 were highly resistant to bile salts at the range of $0.3-2 \%$ after $24 \mathrm{~h}$ of exposure with little viable count reduction to the level of less than 1 log cycle (Table 5). However, $L$. rhamnosus Y1, lost about 50 percent of viability after exposure to 1 and $2 \%$ for $24 \mathrm{~h}$. Since bile plays a role in the defenses of the gut, hence, bile tolerance is a paramount marker in choosing probiotic bacterial strains (Charteris et al., 2000).

Sanders et al., 1996 demonstrated the ability of lactobacilli to grow and metabolize at normal physiological bile concentrations of the gastrointestinal environment. Other reported the effect of food nature and components in the intestine in enhancing probiotics resistance to bile salts. Abbas and Mahasneh, 2015 reported variable degrees of survival of probiotic isolates among different lactobacillus species from camel milk. Studying fermented Korean Kimchi (2016) isolated L.plantarum strains surviving at high bile concentrations.

\section{Antibiotic susceptibility}

Table 6 presents the minimum inhibitory concentration (MIC) breakpoints for the isolates. Strains were considered resistant if they had higher breakpoints compared with that of the European Food Safety Authority Most tested isolates showed resistance to tetracycline, streptomycin, kanamycin and trimethoprim. L.rhamnosus $Y 1$, the most sensitive it was resistant to 4 antibiotics and sensitive to 4 others. L.plantarum 1 M8 was sensitive to 3 antibiotics and resistant to 5 others. L. pentosus M5 and M9 strains were the most resistant isolates exhibiting resistance to 8 antibiotics of the 8 tested. The observed resistance in this study was in agreement with previous reports about Lactobacillus in general (Ashraf et al., 2016). Tetracycline and streptomycin resistance among isolates was higher than that reported by others (Choi et al., 2003) and in agreement with Ammor et al., (Ammor et al., 2008) reported high resistance among Lactobacillus isolates towards aminoglycosides (gentamicin and kanamycin) which was observed in this study. Resistance to such antibiotics is considered natural and intrinsic in lactobacilli due to it being chromosomally encoded. All Lactobacillus strains isolated from traditionally fermented cucumber and cabbage were resistant to streptomycin, vancomycin and gentamycin. Such resistance and in other studies are considered to be intrinsic and therefore not transmissible (Morrow et al., 2012; Kumar et al., 2012).

\section{Adhesion ability of selected Lactobacillus isolates to Caco-2 cells}

The adhesion ability of probiotic lactobacilli to epithelial cells provides substantial benefits such as exclusion of pathogens. It also plays a role in the immunomodulation of the host (Haghshenas et al., 2014) Adhesion to Caco-2 cells of isolates tested in this study varied between species and within species. 
Table.1 Some characteristic of bacterial isolates; all were non-spore forming rods

\begin{tabular}{cccccl}
\hline Isolate & Gram reaction & Catalase & Oxidase & Hemolysis & DNase Gelatinase \\
\hline Y1 & + & - & - & - & -- \\
Y2 & + & - & - & - & -- \\
R21 & + & - & - & - & -- \\
R22 & + & - & - & - & -- \\
L23 & + & - & - & - & -- \\
L24 & + & - & - & - & -- \\
L25 & + & - & - & - & -- \\
M4 & + & - & - & - & - \\
M5 & + & - & - & - & - \\
M6 & + & - & - & - & -- \\
M7 & + & - & - & - & -- \\
M8 & + & - & - & - & - \\
M9 & + & - & - & - & - \\
M11 & + & - & - & - & - \\
B17 & + & - & - & - & - \\
B18 & + & - & - & - & - \\
\hline
\end{tabular}

Table.2 Biochemical identification of Lactobacillus isolates according to Morphological and biochemical tests using API CH 50 strips

\begin{tabular}{ll}
\hline Isolate Code & Species Identification \\
\hline Y1 & Lactobacillus rhamnosus \\
Y2,R21,R22,L23,L24 & Lactobacillus plantarum 1 \\
L25,M4,M5 & Lactobacillus pentosus \\
M6,M8 & Lactobacillus plantarum 1 \\
M11,B17 & Lactobacillus brevis 3 and 1 \\
B18 & Lactobacillus salivarius \\
\hline
\end{tabular}

Table.3 Effect of gastric and intestinal juices on viability of Lactobacillus isolates

\begin{tabular}{cccc}
\hline Isolate & Zero count & 3h count Ph3 & 4h count pH8 \\
\hline Y1 & $8.74 \pm 0.14$ & $8.01 \pm 0.07$ & $7.05 \pm 0.13$ \\
Y2 & $8.35 \pm 0.06$ & $7.87 \pm 0.04$ & $7.33 \pm 0.07$ \\
R21 & $8.23 \pm 0.03$ & $6.10 \pm 0.17$ & $0.00 \pm 0.00$ \\
R22 & $8.50 \pm 0.02$ & $7.47 \pm 0.05$ & $6.52 \pm 0.07$ \\
L23 & $7.53 \pm 0.21$ & $6.30 \pm 0.30$ & $0.00 \pm 0.00$ \\
L24 & $9.56 \pm 0.02$ & $6.79 \pm 0.79$ & $0.00 \pm 0.00$ \\
L25 & $9.46 \pm 0.10$ & $6.49 \pm 0.20$ & $6.00 \pm 0.00$ \\
M11 & $7.80 \pm 0.10$ & $7.40+0.22$ & $6.20+0.06$ \\
L. reuteri & $7.10+0.17$ & $7.52 \pm 0.09$ & $7.06 \pm 0.25$ \\
M4-M9 & Not tested & Not tested & Not tested \\
B7-B18 & Not tested & Not tested & Not tested \\
\hline
\end{tabular}

Results are presented as $\log 10 \mathrm{CFU} / \mathrm{ml}+\mathrm{S} . \mathrm{D}, \mathrm{N}=2$ after $3 \mathrm{~h}$ and $4 \mathrm{~h}$ exposure at $\mathrm{pH} 3$ and 8 respectively 
Table.4 Antagonistic activity of some Lactobacillus isolates against pathogenic bacteria as Indicator

Inhibition zone diameters $(\mathrm{mm})$ of indicator strains

\begin{tabular}{ccccc}
\hline Bacterial isolate & B. cereus & E. coli & MRSA & S. typhimurium \\
\hline Y1 & $60 \pm 0.0$ & $45 \pm 7.1$ & $15 \pm 0.0$ & $50 \pm 0.0$ \\
Y2 & $40 \pm 0.0$ & $36 \pm 0.0$ & $30 \pm 0.0$ & $46 \pm 0.0$ \\
R21 & $43 \pm 1.4$ & $50 \pm 0.0$ & $50 \pm 0.0$ & $38 \pm 2.8$ \\
R22 & $50 \pm 0.0$ & $64 \pm 0.0$ & $35 \pm 7.1$ & $40 \pm 0.0$ \\
L23 & $50 \pm 0.0$ & $44 \pm 2.8$ & $14 \pm 0.0$ & $30 \pm 0.0$ \\
L24 & $42 \pm 0.0$ & $40.5 \pm 2.1$ & $40 \pm 0.0$ & $50 \pm 0.0$ \\
L25 & $50 \pm 0.0$ & $38 \pm 2.8$ & $20 \pm 0.0$ & $28 \pm 0.0$ \\
\hline
\end{tabular}

Inhibition zone diameters $(\mathrm{mm})$ are presented as mean + S.D.; $\mathrm{n}=2$

Table.5 Tolerance of some selected Lactobacillus isolates to varying concentrations of exposure and bile salts after $24 \mathrm{~h}$ of anaerobic incubation

\begin{tabular}{|c|c|c|c|c|c|c|c|c|}
\hline \multicolumn{9}{|c|}{ Bile concentration \% } \\
\hline \multirow{2}{*}{ Isolate } & \multicolumn{2}{|c|}{0.3} & \multicolumn{2}{|c|}{0.5} & \multicolumn{2}{|c|}{1.0} & \multicolumn{2}{|c|}{2.0} \\
\hline & $\mathbf{O h}$ & $24 \mathrm{~h}$ & $\mathbf{0 h}$ & $24 \mathrm{~h}$ & $\mathbf{0 h}$ & $24 \mathrm{~h}$ & $\mathbf{O h}$ & $24 \mathrm{~h}$ \\
\hline Y1 & $\begin{array}{l}6.59 \pm \\
0.11\end{array}$ & $\begin{array}{l}8.80 \pm \\
0.30\end{array}$ & $\begin{array}{l}6.04 \pm \\
0.03\end{array}$ & $\begin{array}{l}6.39 \pm \\
0.07\end{array}$ & $\begin{array}{l}5.10 \pm \\
0.07\end{array}$ & $\begin{array}{l}4.52 \pm \\
0.03\end{array}$ & $5.47 \pm 0.04$ & $3.77 \pm 0.09$ \\
\hline Y2 & $\begin{array}{l}6.07 \pm \\
0.45\end{array}$ & $\begin{array}{l}5.60 \pm \\
0.00\end{array}$ & $\begin{array}{l}6.30 \pm \\
0.17\end{array}$ & $\begin{array}{l}5.18 \pm \\
0.03\end{array}$ & $\begin{array}{l}5.90 \pm \\
0.21\end{array}$ & $\begin{array}{l}5.18 \pm \\
0.05\end{array}$ & $5.94 \pm 0.30$ & $5.18 \pm 0.08$ \\
\hline $\mathbf{R} 21$ & $\begin{array}{l}6.33 \pm \\
0.07\end{array}$ & $\begin{array}{l}7.33 \pm \\
0.35\end{array}$ & $\begin{array}{l}5.92 \pm \\
0.03\end{array}$ & $\begin{array}{l}7.67 \pm \\
0.01\end{array}$ & $\begin{array}{l}5.10 \pm \\
0.17\end{array}$ & $\begin{array}{l}4.95 \pm \\
0.00\end{array}$ & $5.00 \pm 0.00$ & $4.20 \pm 0.17$ \\
\hline R22 & $\begin{array}{l}5.73 \pm \\
0.23\end{array}$ & $\begin{array}{l}5.38 \pm \\
0.03\end{array}$ & $\begin{array}{l}5.78 \pm \\
0.15\end{array}$ & $\begin{array}{l}3.58 \pm \\
0.51\end{array}$ & $\begin{array}{l}6.06 \pm \\
0.11\end{array}$ & $\begin{array}{l}3.59 \pm \\
0.06\end{array}$ & $5.76 \pm 0.14$ & $3.16 \pm 0.04$ \\
\hline $\mathbf{L 2 3}$ & $\begin{array}{l}6.23 \pm \\
0.07\end{array}$ & $\begin{array}{l}8.43 \pm \\
0.23\end{array}$ & $\begin{array}{l}6.17 \pm \\
0.13\end{array}$ & $\begin{array}{l}7.77 \pm \\
0.28\end{array}$ & $\begin{array}{l}6.50 \pm \\
0.16\end{array}$ & $\begin{array}{l}7.34 \pm \\
0.03\end{array}$ & $6.16 \pm 0.02$ & $6.38 \pm 0.00$ \\
\hline L24 & $\begin{array}{l}6.47 \pm \\
0.28\end{array}$ & $\begin{array}{l}9.00 \pm \\
0.00\end{array}$ & $\begin{array}{l}6.18 \pm \\
0.14\end{array}$ & $\begin{array}{l}8.15 \pm \\
0.04\end{array}$ & $\begin{array}{l}6.14 \pm \\
0.10\end{array}$ & $\begin{array}{l}6.32 \pm \\
0.10\end{array}$ & $6.12 \pm 0.26$ & $5.26 \pm 0.00$ \\
\hline L25 & $\begin{array}{l}6.44 \pm \\
0.06\end{array}$ & $\begin{array}{l}8.40 \pm \\
0.36\end{array}$ & $\begin{array}{l}6.40 \pm 0 . \\
02\end{array}$ & $\begin{array}{l}7.41+ \\
0.09\end{array}$ & $\begin{array}{l}6.32 \pm \\
0.19\end{array}$ & $\begin{array}{l}7.20+ \\
0.00\end{array}$ & $6.28 \pm 0.11$ & $5.70 \pm 0.00$ \\
\hline
\end{tabular}

Results are presented as mean + S.D. of viable counts at zero and $24 \mathrm{~h}$ exposure to bile, $\mathrm{n}=2$ 
Table.6 Antibiotic susceptibility profiles of some Lactobacillus isolates of probiotic potential.

\begin{tabular}{lcccccccc}
\multicolumn{1}{l}{ Antibiotic breakpoint ${ }^{\mathrm{a}}(\boldsymbol{\mu g} / \mathbf{m l})$} & \multicolumn{10}{c}{} \\
\hline Isolate & $\mathbf{A}$ & $\mathbf{C}$ & $\mathbf{E}$ & $\mathbf{G}$ & $\mathbf{K}$ & $\mathbf{S}$ & $\mathbf{T e}$ & $\mathbf{T r}$ \\
& $(\mathbf{2})$ & $(\mathbf{4})$ & $(\mathbf{4})$ & $(\mathbf{1})$ & $(\mathbf{3 2})$ & $(\mathbf{1 6})$ & $(\mathbf{1 6})$ & $(\mathbf{1 6})$ \\
\hline & & & & & & & & \\
Y1 & $\mathrm{S}$ & $\mathrm{R}$ & $\mathrm{S}$ & $\mathrm{S}$ & $\mathrm{R}$ & $\mathrm{R}$ & $\mathrm{R}$ & $\mathrm{S}$ \\
M4 & $\mathrm{S}$ & $\mathrm{S}$ & $\mathrm{R}$ & $\mathrm{R}$ & $\mathrm{R}$ & $\mathrm{R}$ & $\mathrm{R}$ & $\mathrm{S}$ \\
M5 & $\mathrm{R}$ & $\mathrm{R}$ & $\mathrm{R}$ & $\mathrm{R}$ & $\mathrm{R}$ & $\mathrm{R}$ & $\mathrm{R}$ & $\mathrm{R}$ \\
M6 & $\mathrm{R}$ & $\mathrm{S}$ & $\mathrm{R}$ & $\mathrm{R}$ & $\mathrm{R}$ & $\mathrm{R}$ & $\mathrm{R}$ & $\mathrm{R}$ \\
M7 & $\mathrm{R}$ & $\mathrm{R}$ & $\mathrm{R}$ & $\mathrm{S}$ & $\mathrm{S}$ & $\mathrm{R}$ & $\mathrm{R}$ & $\mathrm{R}$ \\
M8 & $\mathrm{S}$ & $\mathrm{R}$ & $\mathrm{S}$ & $\mathrm{S}$ & $\mathrm{R}$ & $\mathrm{R}$ & $\mathrm{R}$ & $\mathrm{R}$ \\
M9 & $\mathrm{R}$ & $\mathrm{R}$ & $\mathrm{R}$ & $\mathrm{R}$ & $\mathrm{R}$ & $\mathrm{R}$ & $\mathrm{R}$ & $\mathrm{R}$ \\
L. reuteri DSMZ 20056 & $\mathrm{S}$ & $\mathrm{R}$ & $\mathrm{S}$ & $\mathrm{S}$ & $\mathrm{S}$ & $\mathrm{S}$ & $\mathrm{R}$ & $\mathrm{S}$
\end{tabular}

${ }^{a}$ The breakpoints for Lactobacillus sp. by SCAN category. Minimum Inhibitory Concentration (MIC) equal to or higher than the breakpoint is considered as resistant. (S): Susceptible; (R): Resistant; (A): Ampicillin; (C): Ciprofloxacin; (E): Erythromycin; (G): Gentamicin; (K): Kanamycin; (S): Streptomycin; (Te): Tetracycline and (Tr): Trimethoprim

Table.7 Relative adhesion ability to Caco-2 cells of some selected Lactobacillus isolates.
Test strain
$\log$ CFU/ml Adhered
Adhesion \%

\begin{tabular}{lcl} 
E.coli & $6.39+0.17$ & $100 \%$ \\
L.reuteri & $4.83+\_0.93$ & $75 \%$ \\
M 5 & $6.40+\_0.13$ & $100 \%$ \\
M 6 & $5.30+\_0.28$ & $83 \%$ \\
M 8 & $3.26+\_0.24$ & $51 \%$ \\
M 11 & $5.22+\_0.36$ & $82 \%$ \\
B 17 & $3.88+\_0.30$ & $61 \%$ \\
B 18 & $3.42+\_0.26$ & $54 \%$ \\
\hline
\end{tabular}

Escherichia coli and Lactobacillus reuteri DSMZ 20056 were included as a pathogen ( 100\% relative adhesion) and known probiotic strains respectively

Considering E.coli relative adhesion in our test as 100 percent, $L$. pentosus M5, $L$. plantarum M6 and L. brevis M11, all showed relative adhesion ability above $80 \%$ (Table 7) and it was higher than $L$. reuteri DSMZ 20056 which is a probiotic strain. Low adhesion values were recorded for M8 (51\%) and $L$. salivarius B18 (54\%).

Studying Lactobacillus strains isolated from fermented vegetables recorded much lower adhesion values ranging from $0.45-12.27 \%$ in most cases, it is believed that variations are strain specific and is linked to differences in cell surface structures (Garcia-Ruiz et al., 2014; Hu et al., 2015). Finally, taking all of the above results in consideration, it is clear that traditionally fermented FOODS and vegetables and Makdoos in this case presents a promising source of improved probiotic lactobacilli due to stresses exerted upon the bacteria during the course of ripening of the mix of fermented vegetables. Tested strains isolated in this study are positively rated as 
suitable probiotics, however additional in vitro studies would substantiate fully their medicinal and otherwise uses.

In conclusion, it is becoming increasingly obvious that the traditional fermented foods offer unlimited reservoir of beneficial probiotics acting upon several targets to improve and protect human health. However, in vitro results should be substantiated by in vivo studies

\section{Acknowledgement}

The authors would like to thank the Deanship of Scientific Research of The University of Jordan, Amman, for their financial support. Ms. Sara Hamdan is also thanked for her efforts as a part time research assistant.

\section{References}

Abbas, M.M., Mahasneh, AM. 2014. Isolation of Lactobacillus strains with probiotic potential from camel's milk. Afr. J. Microbiol. Res., 8(15): 1645-1655.

Abbas, M.M., Mahasneh, A.M. 2015. Functional characteristics of Lactobacillus strains isolated from camel milk. British J. Med. Medi. Res., 7(1): 25-39

Ammor, M.S., Belen Florez, A., Van Hoek, A.H.A.M., delos Reayes-Gavilan, C.G., Aart, H.J.M., Margolles, A., Mayo, B. 2008. Molecular characterization of intrinsic and acquired resistance in lactic acid bacteria and bifidobacteria. $J$. Mol. Microbiol. Biotechnol., 14: 6-15.

Angmo, K., Kumari, A., Tek, S., Bahlla, C. 2016. Probiotic characterization of lactic acid bacteria isolated from fermented foods and beverage of Ladakh.LWT- Food Sci. Technol., 66: 428-436.

Argyri, A.A., Zoumpopoulou, G., Karatzas, K.G., Tsaka-Lidou, E., Nychas, G.J., Panagou, E.Z., Tassou, C.C. 2013.
Selection of potential probiotic lactic acid bacteria from fermented olives by in vitro tests, Food Microbiol., 33: 282291.

Ashmaig, A., Hasan, A., ElGachi, E. 2009. identification of lachic acid bacteria isolated from traditional Sudanese fermented cawels milk. Gariss). Afr. $J$. Microbial. Res., 13( 8): 451-457.

Ashraf, R., Smith, Sc. 2016. Commercial lach acid bacteria and probionic strainstolerance to bile, pcpsia and antibiotic In Tn, Food Res. J., 23-(2): 777-789.

Ayed, E.H.E., Verheul, A., Wouters, J.T.M., Smit, G. 2002. Antimicrobial producing wild lactococci isolated from artisanal and non-dairy origins. Int. Dairy J., 12: 145-150.

Balamurugan, R., Chandragunasekaran, A.S., Chellapan, G., Ragaram, K., Ramamoorthi, G., Ramkrishna, B.S. 2014. Probiotic potential of lactic acid bacteria present in homemade curd in southern India. Indian J. Med. Res., 140:345-355.

Begley, M., Ghan, C.G., Hill, C. 2005. The interaction between bacteria and bile. FEMS Microbiol. Rev., 29: 625-651.

Carafa, I., Nardin, T., Larcher, R., Tuohy, K., Franciosi, E. 2015. Identification and characterization of wild lactobacilli and pediococci from spontaneously fermented mountain cheese. Food Microbiol., 48: 123-132.

Charteris, W.P., Kelly, P.M., Morelli, L., Collins, J.K. 2000. Effect of conjugated bile salts on antibiotic susceptibility of bile salt tolerant Lactobacillus and Bifidobacterium isolates. J. Food Protection, 63: 1369-1376.

Chiang, S.S., Pan, T.M. 2012. Beneficial effects of Lactobacillus paracasei subsp. paracasei NTU 101 and its fermented products. J. Appl. Microbiol. Biotechnol., 93: 903-916.

Choi, Y.S., Chang, C.E., Kim, S.C., So, J.S. 
2003. Antimicrobial susceptibility and strain prevalence of Korean vaginal Lactobacillus sp. Anaerobe, 9: 277-280. Dunne, C., O'Mahony, L., Murphy, L., Thornton, G., Morrissey, D., O'Haloran, S., Feeney, M., Flynn, S., Fitzgerald, G., Daly, C., Kiely, B., O'Sullivan, G.C., Shanahan, F., Collins, J.K. 2001. In vitro selection criteria for probiotic bacteria of human origin: Correlation with in vivo findings. $J$. Clin. Nutri., 73(2): 386-392.

EFSA. 2008. Technical guidance prepared by the panel on additive and products or substances used in animal feed on the uptake of criteria used in the assessment of bacterial resistance to antibiotics of human or veterinary importance. EFSA J., 732: 1-15.

Feng, J., Liu, P., Yang, X., Zhao, X. 2015. Screening of immunomodulatory and adhesive Lactobacillus with antagonistic activities against Salmonella from fermented vegetables. World J. Microbio. Biotechnol., 31: 1947-1954.

Gänzle, M., Weber, S., Hammer, W. 1999. Effect of ecological factors on the inhibitory spectrum and activity of bacteriocins. Int. J. Food Microbiol., 46: 207-217.

Garcia-Ruiz, A., de Llano, D.G., EstebanFernandez, A., Requina, T., Bartolome, B., Moreno-Arribas, M.V. 2014. Assessment of probiotic properties in lactic acid bacteria isolated from wine. Food Microbiol., 44: 220-225.

Giraffa, G., Chanishvili, N., Widyastuti, Y. 2010. Importance of Lactobacilli in food and feed biotechnology. Res. Microbiol., 161: 480-487.

Granato, D., Branco, G.F., Nazzaro, F., Cruz, A.G., Faria, J.A.F. 2010. Functional foods and non-dairy probiotic food development: Trends, concepts and products. Compr. Rev. Food Sci., 9(3):
292-302.

Guessas, B., Khal, M. 2004. Characterization of lactic acid bacteria isolated from Algerian arid zone raw goat milk. Afr. $J$. Biotechnol., 3: 339-342.

Guo, X.H., Kim, J.M., Nam, H.M., Park, S.Y., Kim, J.M. 2010. Screening lactic acid bacteria from swine origins for multistrain probiotics based on in vitro functional properties. Anaerobe, 16: 321-326.

Gupta, H. and Malik, R.K. 2007. Incidence of virulence in bacteriocin producing enterococcal isolates. Lait, 87: 587-601.

Haghshenas, B., Abdullah, N., Nami, Y., Radiah, D., Khosroushashi. 2014. Different effects of two newly isolated probiotic lactobacillus sub sp. lactis 44 lac strains from traditional dairy products on cancer cell lines. Anaerobe, 30: 51-59.

Hamady, M.L. 2003. Pickled Eggplants In Lebanese Mountain Cookery. David R. Gordine, Publisher Inc. Jaffrey, New Hampshire 03452. PP 43, 81-83

Hu, J., Wang, C., Ye, L., Yang, W., Huang, H., Meng, F., Shi, S., Ding, Z. 2015. Antitumor immune effect of oral administration of L. plantarum to CT 26 tumor bearing mice. J. Biosci., 40: 5159.

Husmaini Abbas, M.H., Purwati, E., Yuniza, A., Aliman, A.R. 2011. Growth and survival of lactic acid bacteria isolated from by-product of virgin coconut oil as probiotic candidate for poultry. Int. $J$ Poultry Sci., 10: 309-314

Khan, Kang. 2016. PropionicPolemical of nutritionally improved laclzbcillusplenterum DGk-17 isolated from Kimchi-o traditional Korean termeted, Food Eontrol., 60: 88-94.

Kumar, M., Gosh, M., Ganguli, A. 2012. Mitogenic response and probiotic characteristics of lactic acid bacteria isolated from indigenously pickled 
vegetables and fermented bevereges. World J. Microbiol. Biotechnol., 28: 703-711.

Lavilla-Lerma, L., Perez-Pulido, R., Martinez-Bueno, M., Maqueda, M., Valdivia, E. 2013. Characterization of functional, safety and gut survival related characteristics of Lactobacillus strains isolated from farmhouse goat's milk cheeses. Int. J. Food Microbiol., 136(2-3): 136-145.

Lee, J., Yun, H.S., Cho, K.W., Oh, S., Kim, S.H., Chun, T., Kim, B., Whang, K.Y. 2011. Evaluation of probiotic characteristics of newly isolated Lactobacillus spp.: Immune modulation and longevity. Int. J. Food Microbiol., 148(2): 80-86.

Lieven-Le Moal, V., Servin, A.L. 2014. Antiinfective activities of Lactobacillus strains in the human intestinal microbiota: from probiotics to gastrointestinal antinfectious biotherapeutic agents. Clin. Micrbiol. Rev., 27: 167-199.

Liu, X.M., Liu, W.Y., Zhang, Q.X., Tian, F.W., Wang, G., Zhang, H., Chen, W. 2013. Screening of lactobacilli with antagonistic activity against enteroinvasive E.coli. Food Control, 30: 563-568.

Mahasneh, A.M., Hamdan, S., Mahasneh, S.A. 2015. Probiotic properties of Lactobacillus species isolated from local traditionally fermented products. Jordan J. Biol. Sci., 8(2): 81-87.

Maragkoudakis, P.A., Zoumpopoulou, G, Miaris, C., Pot, P., Tsakalidou, E. 2006. Probiotic potential of Lactobacillus strains isolated from dairy products. Int Dairy J., 13:189-199

Messaoudi, S., Manai, M., Kergourlay, G., Prevost, H., Connil, N., Chobert, J.M., Dousset, X. 2013. Lactobacillus salivarius: bacteriocin and probiotic activity. Food Microbiol., 36: 296-304.
Morrow, L.E., Gogineni, V., Malesker, M.A. 2012. Probiotics in the intensive care unit. Nutrition and Clinical Practice, 27(2): 235-241.

Pundir, R.K., Rana, S., Kashyap, N., Kaur, A. 2013. Probiotic potential of lactic acid bacteria isolated from food samples: an in vitro study. J. Appl. Pharm. Sci., 3(3): 85-93.

Rivera-Espinoza, Y., Gallardo-Navarro, Y. 2010. Non-dairy probiotic products. Food Microbiol., 27(1): 1-11.

Rubio, R., Jofre, A., Martin, B., Aymerich, T., Garriga, M. 2014. Characterization of lactic acid bacteria isolated from infant faeces as potential probiotic starter cultures for fermemented sausages. Food Microbiol., 38: 303-311.

Ruggiero, P. 2014. Use of probiotics in the fight against $H$. pylori. World $J$. Gastrointesr. Pathophysiol., 5: 384-391.

Sanchez, B., Ruiz, L., Gueimonde, M., RausMadiedo, P., Margolles, A. 2012. Toward improving technological and functional properties of probiotics in foods. Trends Food Sci. Tech., 26(1): 56-63.

Sanders, M.E., Walker, D.C., Walker, K.M., Aoyama, K., Klaenhammer, T.R. 1996. Performance of commercial cultures in fluid milk applications. J. Dairy Sci., 79(6): 943-955.

SCAN. 2000 Scientific committee on Animal Nutrition Europen Commission. EC). Health and consumer Protection directorate general, scientific opinions PP.1-25.

Shah, N.P. 2007. Functional cultures and health benefits. Int. Dairy J., 17(11): 1262-1277.

Tham, C.S.C., Peh, K.K., Bhat, R., Liong, M.T. 2012. Probiotic properties of bifidobacteria and lactobacilli isolated from local dairy products. Ann. Microbiol., 62: 1079-1087.

Tigu, F., Assefa, F., Mehari, T., Ashanfi, M. 
2016. Probionic property of lachic avid bacteria from traditional formeted condiments: Datts and Awaze. In tn Food Res. J., 23(2): 77-776.

Tropcheva, R., Nikolova, D., Evstatieva, Y., Danova, S. 2014. Antifungal activity and identification of lactobacilli isolated from traditional dairy product Katak. Anaerobe, 28: 78-84.

Tulini, F.L., Winkelstroter, L.K., DeMartinis, E.C.P. 2013. Identification and evaluation of the probiotic potential of Lactobacillus paraplantarum FT259, a bacteriocinogenic strain isolated from Brazilian semi-hard artisanal cheese.
Anaerobe, 22: 57-63. Wang, G., Zhao, Y., Tian, F.W., Jin, X., Chen, H.Q., Liu, X.M., Zhang, X.Q., Zhao, J.X., Chen, Y.Q., Zhang, H., Chen, W. 2014. Screening of adhesive lactobacilli with antagonistic activity against Campylobacter jejuni. Food Control, 44: 49-57.

Zielinska, D., Rzepkowska, A., Radawska, A., Zielinski, K. 2015. In vitro screening of selected probiotic properties of Lactobacillus strains isolated from traditional fermented cabbage and cucumber. Curr. Microbiol., 70: 183-194.

\section{How to cite this article:}

Adel M. Mahasneh, Sari A. Mahasneh. 2017. Probiotic Characterization of Lactic Acid Bacteria Isolated From Local Fermented Vegetables (Makdoos). Int.J.Curr.Microbiol.App.Sci. 6(2): 1673-1686. doi: http://dx.doi.org/10.20546/ijcmas.2017.602.187 